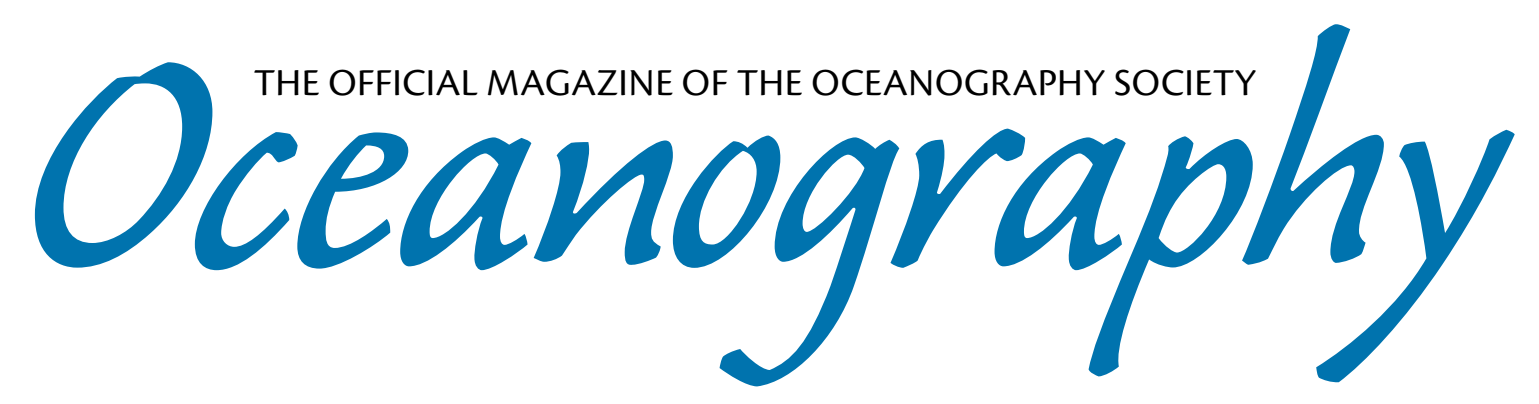

CITATION

Speer, K., and A.M. Thurnherr. 2012. The Lau Basin Float Experiment (LAUB-FLEX).

Oceanography 25(1):284-285, http://dx.doi.org/10.5670/oceanog.2012.27.

$\mathrm{DOI}$

http://dx.doi.org/10.5670/oceanog.2012.27

COPYRIGHT

This article has been published in Oceanography, Volume 25, Number 1, a quarterly journal of The Oceanography Society. Copyright 2012 by The Oceanography Society. All rights reserved.

USAGE

Permission is granted to copy this article for use in teaching and research. Republication, systematic reproduction, or collective redistribution of any portion of this article by photocopy machine, reposting, or other means is permitted only with the approval of The Oceanography Society. Send all correspondence to: info@tos.org or The Oceanography Society, PO Box 1931, Rockville, MD 20849-1931, USA. 


\section{The Lau Basin Float Experiment (LAUB-FLEX)}

BY KEVIN SPEER AND ANDREAS M. THURNHERR

Before 2004, little was known about deep ocean circulation in the Lau Basin, a semi-enclosed basin in the South Pacific Ocean, about $1,500 \mathrm{~km}$ north of New Zealand. This basin hosts a number of back-arc spreading centers with active hydrothermal vents, including the Eastern Lau Spreading Center (ELSC), a Ridge 2000 Integrated Study Site where coordinated interdisciplinary experiments were carried out between 2004 and 2010 (Tivey et al., 2012, in this issue). Answering numerous important questions in hydrothermal research requires an understanding of oceanic circulation on a range of temporal and spatial scales. For example, we need to be able to make flux calculations of heat

Kevin Speer (kspeer@ocean.fsu.edu) is Professor, Department of Earth, Ocean, and Atmospheric Sciences, Florida State University, Tallahassee, FL, USA.

Andreas $M$. Thurnherr is Lamont Associate Research Professor, Division of Ocean and Climate Physics, LamontDoherty Earth Observatory, Columbia University, Palisades, NY, USA. and hydrothermal chemicals and to know the pathways for larval dispersal, which determine colonization of new hydrothermal sites, gene flow, and ultimately the biogeography of vent species. Knowledge of turbulent dispersion (mean squared displacement averaged over groups of floats) enables quantification of spreading rates and direction in complex ocean circulation regimes, and Lagrangian measurement techniques are often used to observe dispersion. Near mid-ocean ridges, however, this approach is still relatively rare (Speer et al., 2003; Jackson et al., 2010).

We studied the deep flow field in the Lau Basin with autonomous floats that are programmed to drift at the depth of hydrothermal plumes (approximately 1,700-1,800 m water depth). The floats periodically return to the surface to obtain their positions via GPS and to transmit their data back to shore using a network of satellites. Five APEX and 10 PROVOR floats were deployed during three scientific expeditions to the ELSC in 2004 and 2005. Of the 15 floats, 11 operated in a fully functional manner; as of the summer of 2011, four are still operating normally. Individual horizontal velocities are fairly isotropic across the basin; on the western side of the basin, speeds of up to $10 \mathrm{~cm} \mathrm{~s}^{-1}$ occur in a deep boundary current. These observations imply that on timescales of months to a year, horizontal dispersal of larvae, chemical signals, or other tracers in the deep interior of the Lau Basin is primarily by turbulent diffusion due to eddies, while on longer timescales, the observed northward mean flow becomes important. As a consequence, nearly isotropic horizontal dispersal of larvae and other vent-related chemical species is expected near and along the ELSC over timescales of up to a year or so.

Although spatial sampling of the floats is sparse, there is qualitative evidence for northward boundary currents along the ridges that bracket the Lau Basin on the east and the west. The overall picture of the large-scale circulation provided by the three-dimensional trajectory map for all floats shows the major components of flow (Figure 1): eddy dispersion near the central ridge (lighter blue trajectories) 
Figure 1. The

Lau Basin is a

semi-enclosed basin

in the tropical South

Pacific Ocean, east of the

Fiji Islands. Below $1,000 \mathrm{~m}$, it

is largely closed to the west by the

Lau Ridge, and to the south and east by

the Tonga Ridge. The Zephyr Shoal in the

north, oriented along $15^{\circ} \mathrm{S}$, blocks the northern

edge of the basin below about 2,000 $\mathrm{m}$. Eleven

three-dimensional trajectories from the LAUB-FLEX

experiment are displayed, with coloring selected to indicate

three major pathways of flow observed over the course of more

than seven years of observation. Several floats are still operating as

of the summer of 2011. The primary sense of circulation is westward and

northward, with outflow at the northwest corner between the Lau Ridge

and the Zephyr Shoals, where a few floats have entered the deep expression of

the South Equatorial Current system. An animation of the trajectories is provided at

http://media.marine-geo.org/video/the-lau-basin-float-experiment-laub-flex-2011.

and Zephyr Shoals (yellow trajectories), northward flow in a western boundary current along Lau Ridge east of Fiji, and the final dispersal into the deep expression of the South Equatorial Current (dark blue trajectories).

Our data do not support the simple anticyclonic circulation scheme inferred early on from hydrography, and our measurements have led to a new view of the circulation in this basin. It has taken many years to build up sufficient data to enable quantitative estimates of circulation in the basin.

We also expect that there is enhanced diapycnal mixing over the rough topography of the spreading ridges in the central Lau Basin. Stratification is weak above these deep-basin spreading centers, and vertical mixing spreads hydrothermal effluent into a range of depths. This vertical mixing plays a role in dispersal together with the lateral mixing and flow measured here directly with floats. The measurements reported here yield new information about circulation and processes acting in deep confined basins with rough topography, and will help to constrain models of heat and chemical transport in the Lau Basin.

\section{ACKNOWLEDGMENTS}

We thank J. Cook for assistance with the figure and two anonymous reviewers for comments on the manuscript. The LAUB-FLEX project was supported by NSF grant 0241785. 마

\section{REFERENCES}

Jackson, P.R., J.R. Ledwell, and A.M. Thurnherr. 2010. Dispersion of a tracer on the East Pacific Rise $\left(9^{\circ} \mathrm{N}\right.$ to $\left.10^{\circ} \mathrm{N}\right)$, including the influence of hydrothermal plumes. Deep-Sea Research Part I 57:37-52, http://dx.doi.org/10.1016/ j.dsr.2009.10.011.

Speer, K.G., M.E. Maltrud, and A.M. Thurnherr. 2003. A global view of dispersion on the mid-ocean ridge. Pp. 287-302 in Energy and Mass Transfer in Marine Hydrothermal Systems. P. Halbach, V. Tunnicliffe, and J. Hein, eds, Dahlem Workshop Report 89, Dahlem University Press, Berlin.

Tivey, M.K., E. Becker, R. Beinart, C.R. Fisher, P.R. Girguis, C.H. Langmuir, P.J. Michael, and A.-L. Reysenbach. 2012. Links from mantle to microbe at the Lau Integrated Study Site: Insights from a back-arc spreading center. Oceanography 25(1):62-77, http:// dx.doi.org/10.5670/oceanog.2012.04. 